\title{
STUDI DESKRIPTIF KADAR DEBU PADA BAGIAN PRODUKSI PT. RAJA BESI SEMARANG TAHUN 2015
}

\author{
Nosa Bagas Isdianto ${ }^{1)}$, Susiyanti ${ }^{2)}$, Teguh Widiyanto ${ }^{3)}$ \\ Jurusan Kesehatan Lingkungan, Politeknik Kesehatan Kemenkes Semarang \\ Jl. Raya Baturaden KM 12Purwokerto, Indonesia
}

\begin{abstract}
Abstrak
Bahan, alat, produksi dan lingkungan kerja berpotensi menimbulkan bahaya bagi kesehatan dan keselamatan kerja. Parameter kadar debu, suhu, kelembaban, kecepatan dan arah angin merupakan hal yang harus diperhatikan bagi pekerja dan lingkungan kerja untuk mengetahui kualitas lingkungan kerja, sumber bahaya, pengendalian resiko dan meminimalisir kecelakaan kerja. Penelitian ini bertujuan untuk mengukur kadar debu di 13 ruang produksi PT. Raja Besi Semarang. Jenis penelitian yang digunakan adalah deskriptif dengan pendekatan crossectional. Hasil pengukuran rata-rata kadar debu $10 \mu \mathrm{m} 9,979 \mathrm{mg} / \mathrm{m}^{3}$, 2,5 $\mu \mathrm{m} 9,17 \mathrm{mg} / \mathrm{m}^{3}, 1 \mu \mathrm{m} \mathrm{11,024} \mathrm{mg/ \textrm {m } ^ { 3 }}$ dan debu total 9,864 mg/m ${ }^{3}$. Rata-rata pengukuran suhu $29,76^{\circ} \mathrm{C}$, kelembaban $65,07 \%$, kecepatan angin 0,61 $/ \mathrm{s}$, arah angin menunjukkan ke arah Timur Laut dan penilaian kondisi sanitasi didapatkan hasil 85,36\%. Peneliti menyimpulkan kadar debu dengan ukuran partikel 1 $1 \mu$ m melebihi standar, 2,5 $\mu \mathrm{m}, 10 \mu \mathrm{m}$, dan debu total memenuhi setandar Kepmenkes NO.1405/Menkes/SK/XI/2002 untuk kandungan debu maksimal di dalam ruangan, selama pengukuran $8 \mathrm{jam}$ adalah $10 \mathrm{mg} / \mathrm{m}^{3}$. Suhu memenuhi setandar $\left(18-30^{\circ} \mathrm{C}\right.$ ), kelembaban memenuhi setandar (6596\%), kecepatan angin melebihi setandar (0,15-0,25 m/s) arah angin menunjukkan ke arah Timur Laut dan kondisi Sanitasi yang sangat baik. Saran yang diberikan kepada peneliti lain adalah selain mengukur kadar debu juga mengukur kapasitas paru pada pekerja.
\end{abstract}

Kata Kunci : Debu, Besi, Kesehatan Lingkungan

\begin{abstract}
[Dust Levels Descriptive Study In the Production Department of PT Raja Besi Semarang 2015] Materials, tools, production and working environment have potential to pose a health and safety danger. Dust levels Parameter, temperature, humidity, wind speed and direction are things to consider for workers and the surrounding working environment to determine the quality of the working environment, source of danger, risk control and minimize accidents. The research objective was measuring the dust levels in 13 production chamber of PT. Raja Besi Semarang. The measurement results shows that the average dust level with 10um particle size was 9.979 $\mathrm{mg} / \mathrm{m}^{3}, 2.5 \mu \mathrm{m} 9.19 \mathrm{mg} / \mathrm{m}^{3}, 1 \mu \mathrm{m} 11.024 \mathrm{mg} / \mathrm{m}^{3}$ and total dust level was $9.864 \mathrm{mg} / \mathrm{m}^{3}$, the average temperature was $29.76^{0} \mathrm{C}$, the average humidity was $65.07 \%$, average wind speed gained $0.61 \mathrm{~m} / \mathrm{s}$ with average wind was Northeast as well as the sanitary conditions assessment results showed $85.36 \%$. The conclusion was was; dust level with $1 \mu \mathrm{m}$ particle size exceed the threshold value, whereas $2,5 \mu \mathrm{m}, 10 \mu \mathrm{m}$, and the total dust level qualify the threshold value stated by Kepmenkes NO.1405/Menkes/SK/XI/2002 that maximum dust content in the air in the measurement room for 8 hours is $10 \mathrm{mg} / \mathrm{m}^{3}$. Temperature meet the requirements $\left(18-30^{\circ} \mathrm{C}\right)$, moisture meets the requirements (65-96\%), the wind speed exceeds the requirements $(0.15$ to $0.25 \mathrm{~m} / \mathrm{s})$ average wind direction Northeast. As well as the sanitation conditions was very good. The proposed suggestion for future researcher was; measuring worker's lung capacity beside the dust level.
\end{abstract}

Keywords $\quad$ : Dust, Iron, Environmental Health

\section{PENDAhULUAN}

Udara merupakan zat yang paling penting setelah air dalam memberikan kehidupan. . Komposisi normal udara terdiri atas gas Nitrogen 78,1\%, Oksigen 20,93\% dan Karbondioksida 0,03\%, sementara selebihnya berupa gas argon, neon, krypton, xenon, dan helium. Udara juga mengandung uap air, debu, bakteri, spora, dan sisa tumbuhtumbuhan.

Masalah pengotoran udara sudah lama menjadi masalah kesehatan pada masyarakat. Pembangunan

1) Email : nosabagas09@gmail.com

2) Email : dolphin_fatih_a@yahoo.com

3) Email : widiyantoteguh@yahoo.co.id yang berkembang pesat khususnya dalam bidang industri dan teknologi menyebabkan terjadinya perubahan komposisi udara melampaui daya dukung lingkungan, hal ini dapat berdampak negatif terhadap manusia, yaitu pencemaran udara atau polus idi permukaan bumi ini.

Debu besi adalah debu anorganik sehingga penyakit paru kerja yang berhubungan dengan debu besi termasuk pneumoconiosis debu anorganik, antara lain: siderosis, welder's siderosis dan siderosilikosis. Pneumoconiosis adalah penyakit 
saluran pernapasan yang disebabkan oleh adanya partikel (debu) yang masuk atau mengendap di dalam paru-paru Selain berdampak kepada pekerja maupun masyarakat di sekitar industri, debu besi ini juga berdampak pada kehidupan tumbuhan karena adanya penutupan pori-pori tumbuhan oleh debu besi sehingga mengganggu jalannya proses fotosintesis.

Dampak yang dapat mencemari lingkungan oleh debu besi dapat dilihat pada daun di sekitar pabrik yang tertutup debu, selain itu pekerja yang bekerja di ruang produksi besi mendapatkan keluhan bahwa debu pada PT Raja Besi sering mengakibatkan gangguan pernafasan pada pekerja.

Tujuan Penelitian ini adalah Mengetahui kadar debu pada 13 bagian produksi di PT. Raja Besi Jalan Setiabudi 117 Srondol Kulon Semarang Kecamatan Banyumanik Kabupaten Semarang

\section{BAHAN DAN METODE}

Metode penelitian yang digunakan adalah penelitian deskriptif, yaitu suatu metode penelitian yang dilakukan dengan tujuan untuk membuat gambaran tentang suatu keadaan secara obyektif, dan memecahkan atau ,menjawab permasalahan yang sedang dihadapi pada situasi sekarang dengan menggunakan pendekatan crossectional

Sampel peneliti adalah udara pada 13 titik sampling yang masing-masing titik sampling mewakili 13 ruangan yang ada di ruangan produksi di PT. Raja Besi. Pengukuran debu di permukiman terdekat menggunakan 2 titik sampling karena dekat dengan sumber pencemar dan banyaknya arah angin yang sering berhembus di sekitar permukiman dan untuk mengetahui keluhan responden dengan adanya paparan debu dengan besar responden $28 \mathrm{KK}$

Analisis data dengan menggunakan Analisis univariat dengan penghitungan mean, membandingkan dengan baku mutu serta dengan tabel, foto dan lampiran.

\section{III.HASIL DAN PEMBAHASAN}

\section{Hasil}

Cara pembuatan pipa besi : bahan baku berupa plat besi lembaran dimasukkan ke mesin Pickling, kemudian masukkan ke mesin potong, setelah plat terpotong plat masuk ke dalam pengatur, kemudian plat yang telah merata digulung kembali di coiler penggulung, masukkan ke mesin Annealing, kemudian plat dipotong, setelah itu plat dipasang pada uncoiler, kemudian bahan masuk ke dalam forming roll, kemudian masuk ke dalam proses pengelasan, setelah dilas bekas las pada pipa dipahat atau diratakan, kemudian roll yang telah dilas dan dipahat masuk ke dalam proses pendinginan dan disempurnakan bentuknya oleh sizing roll dan turn head sebelum dipotong.

Rata-rata hasil pengukuran kadar debu di 13 ruang produksi di PT. Raja Besi Semarang : a. Ukuran pertikel debu $10 \mu \mathrm{m}$ didapatkan hasil $9,979 \mathrm{mg} / \mathrm{m}^{3}$

b. Ukuran pertikel debu 2,5 $\mu \mathrm{m}$ didapatkan hasil $9,17 \mathrm{mg} / \mathrm{m}^{3}$

c. Ukuran pertikel debu $1 \mu \mathrm{m}$ didapatkan hasil $11,024 \mathrm{mg} / / \mathrm{m}^{3}$

d. Kadar Debu Total didapatkan hasil 9,864 mg/m

Rata-rata hasil pengukuran suhu, kelembaban, cuaca, kecepatan dan arah angin, serta penilaian kondisi sanitasi di 13 ruang produksi PT. Raja Besi Semarang

a. Suhu didapatkan hasil $29,76^{\circ} \mathrm{C}$

b. Kelembaban didapatkan hasil $65,07 \%$

c. Cuaca saat pengukuran cerah

d. Kecepatan angin $0,61 \mathrm{~m} / \mathrm{s}$ dengan rata-rata arah angin berhembus ke arah Timur Laut

e. Kondisi Sanitasi didapatkan hasil $85,36 \%$

\section{Pembahasan}

Untuk partikel debu berukuran $1 \mu \mathrm{m}$ tidak memenuhi persyaratan yang ditentukan oleh Kepmenkes NO.1405/Menkes/SK/XI/2002, sedangkan partikel debu dengan ukuran $10 \mu \mathrm{m}, 2,5$ $\mu \mathrm{m}$ dan Debu Total (TSP) memenuhi persyaratan yang ditentukan oleh Kepmenkes NO.1405/Menkes/SK/XI/2002 Tentang Persyaratan Kesehatan Lingkungan Kerja Perkantoran Dan Industri untuk kandungan debu maksimal di dalam udara ruangan dalam pengukuran selama 8 jam adalah $10 \mathrm{mg} / \mathrm{m}^{3}$.

Menurut

Kepmenkes NO.1405/Menkes/SK/XI/2002 Tentang Persyaratan Kesehatan Lingkungan Kerja Perkantoran Dan Industri untuk suhu memenuhi setandar $\left(18-30^{\circ} \mathrm{C}\right)$, kelembaban memenuhi setandar (65-96\%), kecepatan angin melebihi setandar $(0,15-0,25 \mathrm{~m} / \mathrm{s})$ arah angin menunjukkan ke arah Timur Laut seta kondisi Sanitasi yang sangat baik

\section{IV.KESIMPULAN}

\section{Simpulan}

Hasil pengukuran rata-rata kadar debu di 13 ruang produksi di PT. Raja Besi Semarang :

a. Ukuran pertikel debu $10 \mu \mathrm{m}$ didapatkan hasil $9,979 \mathrm{mg} / \mathrm{m}^{3}$

b. Ukuran pertikel debu 2,5 $\mu \mathrm{m}$ didapatkan hasil $9,17 \mathrm{mg} / \mathrm{m}^{3}$

c. Ukuran pertikel debu $1 \mu \mathrm{m}$ didapatkan hasil $11,024 \mathrm{mg} / / \mathrm{m}^{3}$

d. Kadar Debu Total didapatkan hasil 9,864 mg/m $\mathrm{m}^{3}$. Untuk partikel debu berukuran $1 \mu \mathrm{m}$ tidak memenuhi persyaratan yang ditentukan oleh Kepmenkes NO.1405/Menkes/SK/XI/2002, sedangkan partikel debu dengan ukuran $10 \mu \mathrm{m}, 2,5$ $\mu \mathrm{m}$ dan Debu Total (TSP) memenuhi persyaratan yang ditentukan oleh Kepmenkes NO.1405/Menkes/SK/XI/2002 Tentang Persyaratan Kesehatan Lingkungan Kerja Perkantoran Dan Industri untuk kandungan debu maksimal di dalam 
udara ruangan dalam pengukuran selama 8 jam adalah $10 \mathrm{mg} / \mathrm{m}^{3}$.

\section{Saran}

Pengelola dan pengawas perusahaan sebaiknya melakukan perawatan dan pemeliharaan terhadap mesin untuk mengurangi kadar debu dari hasil produksi.

Pada ruang produksi sebaiknya di lengkapi dengan alat scrubbing untuk mengurahi kadar debu pada saat roses produksi.

Peletakan mesin blower (penyedot debu) lebih dekat dengan mesin atau sumber debu.

Sebaiknya perlu ditingkatkan lagi pengawasan pemakaian Alat Pelindung Diri pada pekerja dengan memberikan sanksi bagi yang melanggar. Sanitasi di PT. Raja Besi perlu dijaga dan ditingkatkan lagi agar jadi lebih baik

\section{DAFTAR PUSTAKA}

Aditama 2002. Penyakit Paru Akibat Kerja. Pendidikan Kedokteran Berkelanjutan. Jakarta: Yayasan Penerbit Ikatan Dokter Indonesia http: //www.fkm.undip.ac.id

Andan T Dinata, 2011 Tentang Proses Pengolahan Besi. http//www.byantech.com

Azizah Rosmawati. 2013.Studi Deskriptif Kualitas Udara di Tempat Pembakaran Batu Kapur di Desa Karangdawa Kecamatan Margasari Kabupaten Tegal

Azrul Azwar, 1986, Pengantar Ilmu Kesehatan Lingkungan, Jakarta: Mutiara Sumber Widya

Cahyono Tri. 2014.Pedoman Penulisan Proposal dan Karya Tulis Ilmiah, Purwokerto: JKL Kemenkes Purwokwerto

Daryanto, 1995, Masalah Pencemaran Udara

Depkes RI No 1999 h 5-7 tentang Pedoman Instalasi Gas Medis Rumah Sakit

Fardiaz, Srikandi. 2003. Polusi Air Dan Udara.Yogyakarta

Jenie, B.S.L., 1989, Sanitasi dalam Industri Pangan, PAU Pangan dan Gizi IPB Bogor.

KEPMENKES No. 1405/MENKES/SK/XI/2002 tentang Persyaratan Kesehatan Lingkungan Kerja Perkantoran dan Industri.
Mangku Sitepoe, 1997, Usaha Mencegah Pencemaran Udara.

Mukono, HJ., 2008, Pencemaran Udara dan Pengaruhnya terhadap Gangguan Saluran Pernafasan, Surabaya.

Mulia, Ricky M., 2005, Kesehatan Lingkungan, Yogyakarta : Penerbit Graha Ilmu.

Peraturan Pemerintah Republik Indonesia No. 41 tahun 1999, Baku Mutu Udara Ambien Nasional, http://www.ppri.co.id.

Permenaker No. 13/MEN/X/2011 tentang Nilai Ambang Batas Faktor Fisik dan Kimia di Tempat Kerja.

PP No. 41 tahun 1999 Pengendalian Pencemaran Udara.

Riyadi, Slamet, et.al., 1982, tentang Pencemaran Udara.

Sastrawijaya Tresna, 1991, tentang Pencemaran Lingkungan

Santjaka Aris, 2008, tentang Statistik untuk Penelitian Kesehatan.

Soedirman, 1975, Kriteria Pencemaran Udara dan Air/ Kesehatan Masyarakat Depkes RI No. 13/ tahun IV, Jakarta

Syukri, S., 1999, Kimia Dasar 3, ITB Bandung.

Suparlan, 1981, Pedoman Pengawasan Hygiene Sanitasi Tempat-tempat Umum, Surabaya : Percetakan Dua Tujuh.

Suryana Yayan, 2004, tentang Mudah dan Aktif Belajar Kimia.

UU No. 1 tahun 1970 tentang Keselamatan Kerja.

UU No. 5 tahun 1984 tentang Perindustrian.

Wardhana Arya Wisnu, 2004, tentang Dampak Pencemaran Lingkungan.

Yanuar Tri Wibowo, 2010, Studi tentang Kadar Debu pada Pabrik Kayu UD. Hasil Rawmill di Kawasan Industri Kelurahan Lomanis Kecamatan Cilacap Tengah Kabupaten Cilacap. 